\title{
Environmental stress upon hepatopancreatic cells of freshwater prawns (Decapoda: Caridea) from the floodplain of Paraná River
}

\author{
Pablo Collins
}

Instituto Nacional de Limnología (CONICET-UNL) Ciudad Universitaria, Pje El Pozo s/n, 3000 Santa Fe Santa Fe Argentina TE 0054-0342-4511645 int 113, Fac. de Bioq. y Cs. Biol. UNL, Fac. de Tecnología y Ciencias, UADER; pcollins@arnet.com.ar

Received 10 March 2010; revised 11 April 2010; accepted 17 April 2010.

\section{ABSTRACT}

In order to evaluate the influence of stressed environments on hepatopancreatic cells of freshwater prawns, Macrobachium borellii Nobili, 1896 and Palaemonetes argentinus Nobili 1901, (Crustacea, Decapoda, Palaemonidae) were collected at three different aquatic environments with different relationship to urban development in Argentina. Furthermore the effects of several cypermethryn concentration on hepatopancreatic cell of $M$. borellii and $P$. argentinus were evaluated in a laboratory assays. The " $\mathrm{N}$ " 1" lake (Santa Fe Argentina) which is more affected by the anthropogenic pressure and "Don Felipe" lake which is still not strongly by human activities were the studied sites from the floodplain of Paraná river. While Alejandra lake was the intermedia effects sites. Different damaged ultrastructures were found in F-and R-cells of prawns in the stressed lake. The predominant features were: disrupted the microvillous border, swelled mitochondria, reduction of endoplasmic reticulum, dyctiosomes, glycoproteins, desnaturalization of vacuole membrane and premature autolysis. Moreover the F-cell number was higher in the environment near to city than in the others sites. Similar effects were observed in the cypermethryn assays. The observations clearly indicate that the ultrastructure of midgut gland in the both palaemonids varies depending on the site from which animals are collected and the biocid presence. So, in this case it can be stated that the hepatopancreas histology of freshwater prawns is a good tool to monitor the impact of a stressed environment upon freshwater prawns.
Keywords: Palaemonidae; Midgut Gland; Shrimp; Hepatopancreas; Environmental Stress

\section{INTRODUCTION}

Freshwater prawns are an important and abundant group in the floodplain of the Paraná River, mainly the species Macrobrachium borellii Nobili, 1896 and Palaemonetes argentinus Nobili, 1901. Both prawns have as habit the lotic and lentic environment from La Pampa region, $\mathrm{Ar}$ gentina [1]. This area is characterized by intensive farming, and urban-industries development. Thus the aquatic environment gathers several elements which affect the quality of the rivers and lakes, mainly at the rain events [2]. The nutrient increase, toxins presence and others xenobiotic input, such as biocid and heavy metals, provoke changes in the normal conditions that according to inflow regime (sewage of various degree of treatment, thermal regime, weather conditions and land use) affects the quality conditions of the receptors [3,4].

In the last decades there have been many studies about the influences of exogenous factors upon crustaceans, being the majority of these researches made as laboratory tests. Such works revealed important basic data, and it can be refered to in case of evaluating the environmental influences upon hepatopancreas. There exists a close correlation with different kind of stresses and the ultrastructure of hepatopancreas [5-17]. Some products and/or household waste, such as industrial discharges, pesticides or sewage are transformed and degraded through various reactions with other biotic and abiotic components, when they get into the river. These elements may alter the hepatopancreatic cells and it could be used as biological markers so as to assess the toxic properties of the environmental contaminants [18-20].

The aim of the present work is to compare the ultrastructure of the hepatopancreatic cells of M. borellii and 
$P$. argentinus freshwater prawns at three natural environments with different quality water, in relationship with the biocid use, human activities or land use.

\section{MATERIALS AND METHODS}

\subsection{Sampling Prawns}

Juveniles, males and females of $M$. borellii and P. argentinus (Crustacea, Decapoda, Palaemonidae) were sampled in the lakes "Don Felipe" ( $\left.31^{\circ} 39^{\prime} \mathrm{S}, 60^{\circ} 41^{\prime} \mathrm{W}\right)$, "Alejandra" ( $\left.31^{\circ} 45^{\prime} \mathrm{S}, 60^{\circ} 31^{\prime} \mathrm{W}\right)$ and " $\mathrm{N}^{\circ} 1^{\prime}$ " (31 $31^{\circ} 40^{\prime} \mathrm{S}$, $60^{\circ} 30^{\prime} \mathrm{W}$ ) (Santa Fe, Argentina) during a time of low and high water phases of the flooding cycle (winter and summer, respectively) (Figure 1), and they samples were immediately taken to laboratory.

\subsection{Sites of Study}

The three lakes are placed in the Paraná River floodplain, and they have different relations with human activities and land use. In this river, the water level declined from summer to winter, with a new flooding pulse in spring. They have an average annual discharge of $18,000 \mathrm{~m}^{3} / \mathrm{s}$ and a peak of $60,000 \mathrm{~m}^{3} / \mathrm{s}$ [21]. The flooding water of the lentic bodies in the alluvial valley dilutes the biotic densities of the communities, and during the isolation or low water phase these concentrations recover rapidly. The animal densities show important oscillations among the lakes depending on its volume, distance to the river, amplitude-longitude of flooding pulse and time of water residence [22-24].

"Don Felipe" is an oxbow lake close to the Colastiné River which is a secondary branch directly connected to the main channel (Figure 1). This fact changes its volume depending on the input of water flow from the Colastiné River. In the isolated phase, its maximum and mean depth is $2 \mathrm{~m}$ and $0.66 \mathrm{~m}$ respectively [25]. The main industrialized cities occur about $400 \mathrm{~km}$ away from studied site. Most of the wasted material (e.g. from food industries) are rapidly dissolved when it reaches the flood valley.

"Alejandra lake" is an overflow lake with a direct connection to the Coronda River with a total length of $900 \mathrm{~m}, 1.8 \mathrm{~m}$ depth and it has an area of 75,000 $\mathrm{m}^{2}$ approximately (Figure 1). The land use near this lake is low with a scarce impact on the environment. It is a weekend residential area but it is near to Santa Fe and Santo Tome cities.

" $\mathrm{N}^{\circ} 1$ " is an abandoned meander scroll lake (Figure 1) with a $0.55 \mathrm{~m}$ depth average during the isolated phase (Collins, unpublished) located close to the Salado river (a river with high dissolved contents salt), and its volume changes depending on the input of water flow from the Salado and Santa Fe rivers. During the high water period, the water Salado River is retained by the Paraná system. The Salado River passes through a series of industries and farmlands in which biocides and fertilizers are applied upon them. Moreover industrial discharges and waste-water emitted from the cities (Santa $\mathrm{Fe}$ and Santo Tomé) are poured into the last sections of the river.

\subsection{Measurement of Water Parameters}

The target variables to analyze in each sampling event were taken in the top layer and three meters from the coast line. These were water temperature; conductivity; $\mathrm{pH}$; transparency; nitrate; ammonia; orthophosphate; dissolved oxygen; demand biological of oxygen 5 (DBO5); glyphosate; lead and copper. The samples were collected in polyethylene bottles and preserved at $2-4^{\circ} \mathrm{C}$ to posterior analysis in some cases. Temperature, conductivity, $\mathrm{pH}$ and dissolved oxygen were taken in situ with digital sensors (Hanna HI9143, HI991003, HI9033). Transparency was measured with Secchi disc. All the analytical methods, conformed to EPA methods [26] or Standard Methods [27], were determined by a spetrophotometer Metrolab330 (nitrate; ammonia; orthophosphate), a spetrophotometer Perkin Elmer (limit $4 \mathrm{ug} / \mathrm{L})$ (heavy metals) and with a high precision liquid cromatography (limit $0.2 \mathrm{ug} / \mathrm{L}$ ) (biocid). The parameters were sampled weekly in a month during summer and winter.

\subsection{Hepatopancreatic Cells Evaluation with TEM}

Dissections of the midgut glands were done for three juveniles, males and females of both prawns (M. borellii and $P$. argentinus) in intermolt stage according to Drach and Tchernigovtzeff [28] from the three lakes. Adults without gonadal maturation evidence were used. Dissections were conducted under a binocular microscope and placed in $2 \%$ cold glutaraldehyde solution at $\mathrm{pH} 7.4$ for $2 \mathrm{hr}$ at $1-4^{\circ} \mathrm{C}$. The tissues were then washed in several changes of Sörensen buffer followed by postfixation in $2 \%$ osmium tetroxide solution for $2 \mathrm{hr}$ at $1-4^{\circ} \mathrm{C}$. After dehydration in graded ethilic alcohol the material was embedded in (ERL) araldite resin. Sections with gold interference colours were obtained using a Reichert-Jung Ultramicrotome with a glass and a diamond knife and then mounted on coated copper slot grids. The hepatopancreas sections in the grids were then double stained in uranyl acetate (saturated solution in 70\% methanol, 4 h) followed by lead citrate $(5 \mathrm{~min}$ ) and viewed in a Siemens Electron Microscope 101. The cell types were identified and quantified in each observed section ( 5 for each specimen). 


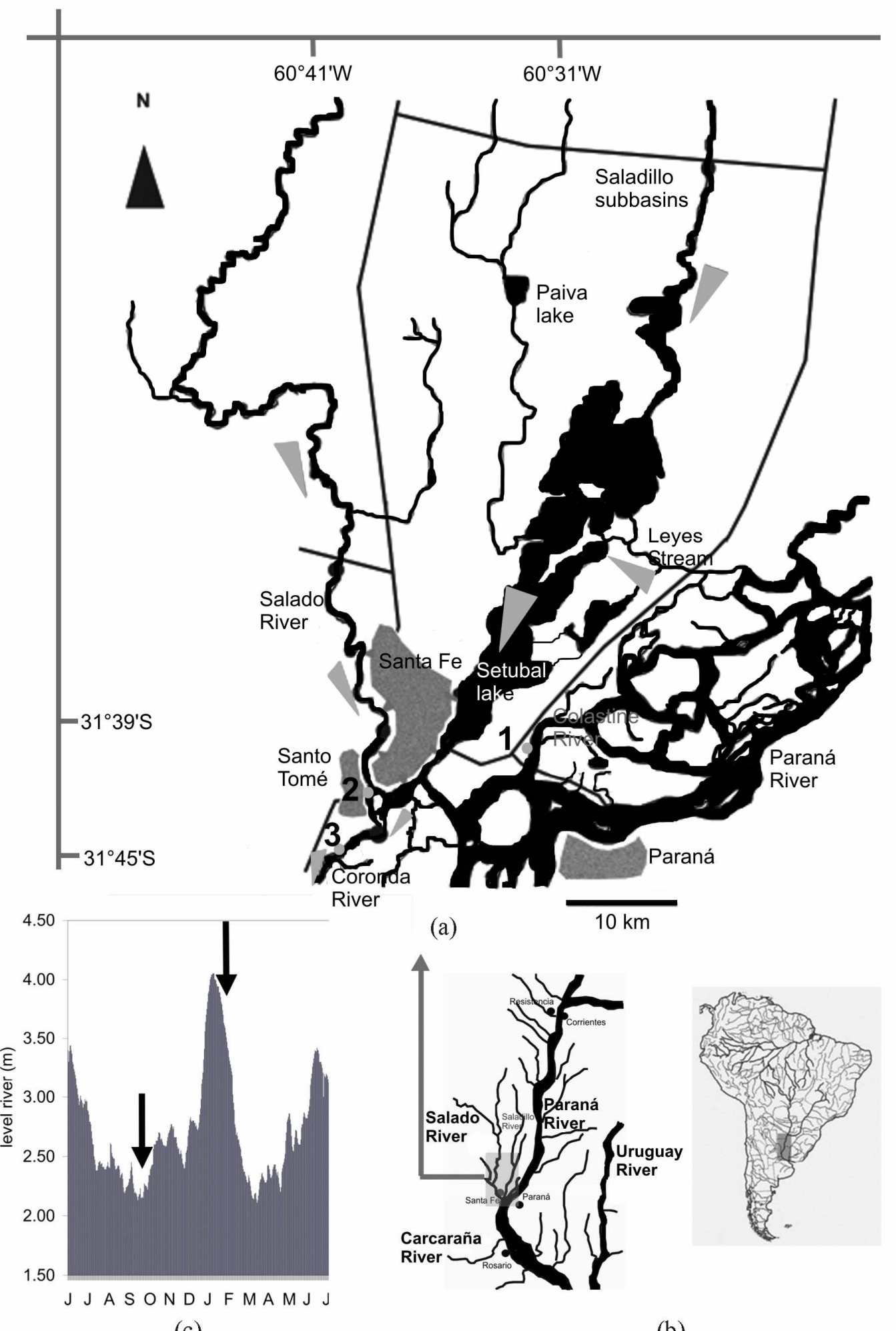

(c)

(b)

Figure 1. Study sites in the floodplain of Paraná Medio River (Santa Fe, Argentina). A) Main rivers and cities indicating the three sampling environments (1: Don Felipe, 2: $\mathrm{N}^{\circ} 1,3$ : Alejandra). B) Main rivers in the de la Plata Systems. C) Seasonal variation of water level in the Paraná Rriver (Santa Fe port limnigraph) (arrows indicated the sampling time). 


\subsection{Laboratory Assays}

In order to evaluate on the hepatopancreatic cell of the prawns the effects of cypermethrin, an extensively biocid used in the farms and urban region, was done a laboratory assays. The biocid was used in its commercial form (Sherpa ${ }^{\circledR}$ : cypermethrin). Prawns (M. borellii and $P$. argentinus) were kept in plastic containers of $0.9 \mathrm{~m}^{2}$ and 401 with a density of $55 \mathrm{ind} / \mathrm{m}$. The nominal sublethal concentrations (cypermethrin (CY): 0.01; 0.001 and $0.0001 \mu \mathrm{g} \mathrm{CY/l)} \mathrm{[29]} \mathrm{were} \mathrm{applied} \mathrm{only} \mathrm{once.} \mathrm{The}$ protocol was: first a continuous flow of water without biocid of $1 \mathrm{ml} / \mathrm{s}$ during 15 days in all containers. After that, the solutions with biocid were applied in the same flow rate $(1 \mathrm{ml} / \mathrm{s})$ during one day. Later on the flow returned to water without cypermethrin. The control group was treated the similar forms in order to flow rate and experience time. The prawns were daily fed with fish muscle "ad libitum" and the mortality was registered in all containers. The experience lasted 45 days. Each seven day, the prawn hepatopancreas in intermolt phase were dissected, and they were processed by a routine histological method (dehydrated in alcohol series and embedded in paraffin wax). They were cut into thin sections of $6 \mu \mathrm{m}$ thickness by a rotative microtome. The hystological cuts of these organs were stained with haematoxylin and eosin to observe of the biocide effects in the light microscope ( 5 cut for each prawns). The hepatopancreatic cells were identificated and quantificated.

\subsection{Data Analysis}

Water quality parameters of each environment were compared with ANOVA and Tukey post-test. In the same way, differences in hepatopancreatic cell number were evaluated with ANOVA. In the assays, survival and he- patopancreatic cell data from control and experimental groups were analysed with ANOVA in conjunction with Tukey post-test too. All data were previously evaluated to normality and homoscedasticity [30].

\section{RESULTS}

\subsection{Environment Quality}

In all the lakes, significant differences (ANOVA $p<0.05$ ) were registered for some parameters and sampling time (Table 1), being the conductivity in " $\mathrm{N}^{\circ} 1$ " lake (near the Salado River) the highest unlike. Furthermore, these differences were high for both sampling periods, with a decrease values in summer during flooding period (Table 1). The $\mathrm{pH}$ was not similar among all the sites, but differences between floods and drought phases occur only in the environment near to the Coronda River. Dissolved oxygen did not differ in the three lakes, being the values lower during winter. Nutrients, such as orthophosphorous, were different between Don Felipe and the other lakes, corresponding high values in summer (Table 1). Nitrate values got the highest level in the Coronda River (Alejandra lake). The unlike data of winter and summer were not relevant ( $p>0.05)$. Ammonia concentration oscillated from 0.006 (Don Felipe summer) to $0.069\left(\mathrm{~N}^{\circ} 1\right.$ winter), showing difference between sampling time. The unlike values among sites was not significantly (Table 1). DBO5 was bigger in the environment near the Coronda River, receiving its water from the Salado and Santa Fe Rivers (Figure 1). In summer, all lakes have a distinct DBO5 but without statistically significance, except in Don Felipe lake. In low water phase (Table 1), glyphosate, residues of glyphosate, and lead were registered in the $\mathrm{N}^{\circ} 1$ lake near the Santa $\mathrm{Fe}$ and Santo Tomé cities.

Table 1. Mean and standard deviations of environmental parameters measured in the three lakes (Don Felipe, $\mathrm{N}^{\circ} 1$ and Alejandra lakes) and two sampling times.

\begin{tabular}{|c|c|c|c|c|c|c|}
\hline & \multicolumn{2}{|c|}{ Don Felipe lake } & \multicolumn{2}{|c|}{$\mathrm{N}^{\circ} 1$ lake } & \multicolumn{2}{|c|}{ Alejandra lake } \\
\hline & winter & summer & winter & summer & winter & summer \\
\hline Temperature ${ }^{\circ} \mathrm{C}$ & $14.8 \pm 1.63^{\mathrm{b}}$ & $23.7 \pm 1.11^{b}$ & $13.6 \pm 1.56^{\mathrm{b}}$ & $23.8 \pm 0.97^{b}$ & $14.7 \pm 1.12^{b}$ & $23.9 \pm 1.12^{b}$ \\
\hline Conductivity $\mu \mathrm{S} \mathrm{cm}^{-1}$ & $150 \pm 30.3^{\mathrm{ab}}$ & $104 \pm 19.3^{\mathrm{ab}}$ & $5580 \pm 1337.9^{\mathrm{ab}}$ & $994 \pm 29.8^{\mathrm{ab}}$ & $261 \pm 55.2^{\mathrm{ab}}$ & $128 \pm 17.3^{\mathrm{ab}}$ \\
\hline Transparency cm & $27.5 \pm 2.38^{b}$ & $16.7 \pm 3.79^{b}$ & $29.5 \pm 3.00^{\mathrm{b}}$ & $16.7 \pm 3.79^{b}$ & $31.8 \pm 7.89^{\mathrm{b}}$ & $13.0 \pm 5.29^{b}$ \\
\hline $\mathrm{pH}$ & $6.9 \pm 0.29^{\mathrm{a}}$ & $6.7 \pm 0.05^{\mathrm{a}}$ & $7.7 \pm 0.20^{\mathrm{a}}$ & $7.5 \pm 0.14^{\mathrm{a}}$ & $7.3 \pm 0.12^{\mathrm{ab}}$ & $6.8 \pm 0.08^{\mathrm{ab}}$ \\
\hline Dissolved oxygen $\mathrm{ml} \mathrm{l}^{-1}$ & $8.8 \pm 1.20^{b}$ & $6.4 \pm 1.09^{b}$ & $9.2 \pm 0.60^{\mathrm{b}}$ & $5.9 \pm 2.69^{b}$ & $9.6 \pm 1.23^{b}$ & $7.9 \pm 0.29^{b}$ \\
\hline $\mathrm{DBO}_{5} \mathrm{ml} \mathrm{l}^{-1}$ & $3.1 \pm 1.68^{\mathrm{ab}}$ & $1.8 \pm 0.69^{\mathrm{ab}}$ & $3.3 \pm 2.25^{\mathrm{a}}$ & $3.7 \pm 0.52^{\mathrm{a}}$ & $4.5 \pm 4.96^{\mathrm{a}}$ & $4.2 \pm 0.87^{\mathrm{a}}$ \\
\hline nitrate $\mathrm{mg} \mathrm{l}^{-1}$ & $1.5 \pm 0.28$ & $1.8 \pm 0.25$ & $1.5 \pm 0.61$ & $1.5 \pm 0.31$ & $2.3 \pm 1.20$ & $2.8 \pm 1.31$ \\
\hline ammonia $\mathrm{m} \mathrm{l}^{-1}$ & $0.026 \pm 0.018^{b}$ & $0.009 \pm 0.006^{\mathrm{b}}$ & $0.037 \pm 0.028^{b}$ & $0.013 \pm 0.015^{b}$ & $0.023 \pm 0.017^{b}$ & $0.012 \pm 0.002^{b}$ \\
\hline orthophosphate $\mathrm{mg} \mathrm{l}^{-1}$ & $1.6 \pm 1.06^{\mathrm{a}}$ & $1.1 \pm 0.62^{\mathrm{a}}$ & $0.7 \pm 0.27^{\mathrm{ab}}$ & $2.1 \pm 0.20^{\mathrm{ab}}$ & $0.6 \pm 0.64^{\mathrm{ab}}$ & $2.6 \pm 0.33^{\mathrm{ab}}$ \\
\hline glyphosate* $\mu \mathrm{g}^{-1}$ & $<0.2$ & $<0.2$ & 3.2 & $<0.2$ & $<0.2$ & $<0.2$ \\
\hline $\mathrm{Pb} \mu \mathrm{g}^{-1}$ & $<4$ & $<4$ & 49 & $<4$ & $<4$ & $<4$ \\
\hline $\mathrm{Cu} \mu \mathrm{g} \mathrm{l}^{-1}$ & $<5$ & $<5$ & 55 & 7.2 & $<5$ & $<5$ \\
\hline
\end{tabular}

Significant differences according to ANOVA and Tukey post test $(\mathrm{p}<0.05)$ a) among environment; b) between sampling times; *glyphosate and their metabolite (AMPA). 


\subsection{Hepatopancreatic Cells}

There have been alterations in the midgut glands of juveniles, males and females of both prawns species from "No 1" lake of Los Sapos island near Santo Tomé and Santa Fe cities and Alejandra lake. The variability of the damage degree was important. This depended on the prawn origen, and the seasons (low and high water level and temperature). The major alterations for both prawn species were observed in the F- and R-cells, and the percentage of the cell type was differed from those prawns in Don Felipe lake (mainly F-cell) (Table 2). Some prawns from Alejandra lake show similar alterations than those from $\mathrm{N}^{\circ} 1$ lake. The difference was observed in the affected cell number, and/or in the intensity of the alteration. Both prawn species showed similar hepatopancreatic cell frequency in all lakes and seasons (Table 2).

In apical zone of the alterated F-cells showed a damaged microvilli border. The endoplasmic reticulum (Figure 2(f)) and the mitochondria were more abundant and swelled, and the cristae of the last was damaged and increased in number compared with the mitochondria of those prawns from Don Felipe lake. Endoplasmic reticulum was either broken up into vesicles and/or exhibits dilated profiles (Figures 2(a), (c), (f), (h) and (i)). The glycoproteins granules and others organelles were increased too, e.g. in the basal region. Amorphous corpuscles with high electron density were found in the cytoplasm (Figures 2(a), (b), (f) and (g)). In the most affected F-cells (mainly in $\mathrm{N}^{\circ} 1$ lake) organelles lysis, including cell nucleus were observed without breaking the wall cell (Figures 2(b), (d) and (g)). The normal F-cells ( $M$. borellii and $P$. argentinus) belonging to "Don Felipe" lake showed abundant rER without dilated profiles in the apical zone. The organelles have a homogeneous distribution, e.g. the cytoplasm contains glycoprotein (or free ribosomes), peroxisomas, vesicles and few and small mitochondria. In the basal region, it is more frequently found the presence of Golgy systems with distended cisterns, and surrounded by small and dense vesicles.

The R-cells of prawns from $\mathrm{N}^{\circ} 1$ and Alejandra lakes were affected in similar ways. The main alterations were: in the apical zone of R-cells, the microvilli border was somewhat shortened and sometimes it lacked the microvillar core filaments (Figures 3(a), (b) and (e)). The endoplasmic reticulum was disrupted and the number of residual bodies increased. The mitochondria were swelled and sometimes its walls became deteriorated (Figures 3(b), (e), (f) and (g)). The lipid vacuole had an abrading multilayered membrane (Figures 3(b) and (e)). Material with high electron density was observed near this vacuole in the apical zone (Figure 3(a)). R-cells with premature autolizing appearance were frequent (Figures 3(d), (f) and (g)). In the basal region, there were few glycoprotein granules, and only the mitochondria was increased and swelled, and its cristae was damaged (Figures 3(c), (d) and (g)). The normal R-cells of prawns from Don Felipe Lake have in apical zone a large number of mitochondria, vesicles and glycoprotein, which are prolonged in concentrated below the apical plasma membrane. The undamaged microvillous border was regular in all the extensions. In the basal region endoplasmic reticulum (rER and $\mathrm{sER}$ ), glycoprotein granules and many mitochondria were observed. The B-cells did not show alterations that differ from the normal of hepatopancreatic cell cycles (Figures 4(a) and (b)) except affections in some B-cells, main in $\mathrm{N}^{\circ} 1$ lake, where autolising of organelles were registered (Figures 4(c) and (d)).

Other changes, such as basophyles vacuole groups and differents residuals bodies, were observed in apical zone of the F-cells in both species. Moreover, evident autolising of the organelles (Figures 5(a), (b) and (e)) and indefinable elements associated with residuals bodies in R-cells with abundant and distended cisterns of endoplasmic reticulum were frequent in the studied species from $\mathrm{N}^{\circ} 1$ lake (Figures 5(c) and (d)).

\subsection{Low and high water Level and Temperature}

The alterations were detected for both seasons and in the same studied sites. The highest number of damaged cell was registered in winter with low water level and tem-

Table 2. Hepatopancreatic cell frequency of two prawns and three lakes (Don Felipe, $\mathrm{N}^{\circ} 1$ and Alejandra lakes) during two sampling times (winter and summer) (540 total observed sections).

\begin{tabular}{|c|c|c|c|c|c|c|}
\hline \multirow[b]{2}{*}{ M. borellii } & \multicolumn{2}{|c|}{ Don Felipe lake } & \multicolumn{2}{|c|}{$\mathrm{N}^{\circ} 1$ lake } & \multicolumn{2}{|c|}{ Alejandra lake } \\
\hline & winter & summer & winter & summer & winter & summer \\
\hline F-cell & $29 \pm 1.6^{a}$ & $32 \pm 1.1^{\mathrm{a}}$ & $49 \pm 6.6^{\mathrm{ab}}$ & $43 \pm 5.7^{\mathrm{ab}}$ & $38 \pm 2.2^{\mathrm{a}}$ & $39 \pm 6.1^{\mathrm{a}}$ \\
\hline R-cell & $35 \pm 3.3^{\mathrm{a}}$ & $39 \pm 4.3^{\mathrm{a}}$ & $25 \pm 5.9^{\mathrm{a}}$ & $23 \pm 6.8^{\mathrm{a}}$ & $32 \pm 5.2^{\mathrm{a}}$ & $37 \pm 4.6^{\mathrm{a}}$ \\
\hline B-cell & $36 \pm 2.8^{\mathrm{ab}}$ & $29 \pm 1.9^{\mathrm{ab}}$ & $26 \pm 3.4^{\mathrm{ab}}$ & $34 \pm 7.9^{\mathrm{ab}}$ & $30 \pm 8.9^{\mathrm{ab}}$ & $24 \pm 2.0^{\mathrm{ab}}$ \\
\hline \multicolumn{7}{|l|}{ P. argentinus } \\
\hline F-cell & $32 \pm 6.3^{\mathrm{ab}}$ & $25 \pm 3.1^{\mathrm{ab}}$ & $54 \pm 5.6^{\mathrm{ab}}$ & $46 \pm 4.7^{\mathrm{ab}}$ & $36 \pm 3.2^{\mathrm{a}}$ & $33 \pm 1.2^{\mathrm{a}}$ \\
\hline R-cell & $37 \pm 5.3^{\mathrm{a}}$ & $43 \pm 4.3^{\mathrm{a}}$ & $23 \pm 3.9^{\mathrm{ab}}$ & $31 \pm 4.8^{\mathrm{ab}}$ & $32 \pm 5.5^{\mathrm{a}}$ & $37 \pm 4.6^{\mathrm{a}}$ \\
\hline B-cell & $31 \pm 2.3^{\mathrm{a}}$ & $32 \pm 3.7^{\mathrm{a}}$ & $23 \pm 3.0^{\mathrm{a}}$ & $23 \pm 6.3^{\mathrm{a}}$ & $32 \pm 4.7^{\mathrm{a}}$ & $30 \pm 1.2^{\mathrm{a}}$ \\
\hline
\end{tabular}

Significant differences according to ANOVA and Tukey post test $(\mathrm{p}<0.05)$. ${ }^{\mathrm{a}}$ among environment; ${ }^{\mathrm{b}}$ between sampling times. 

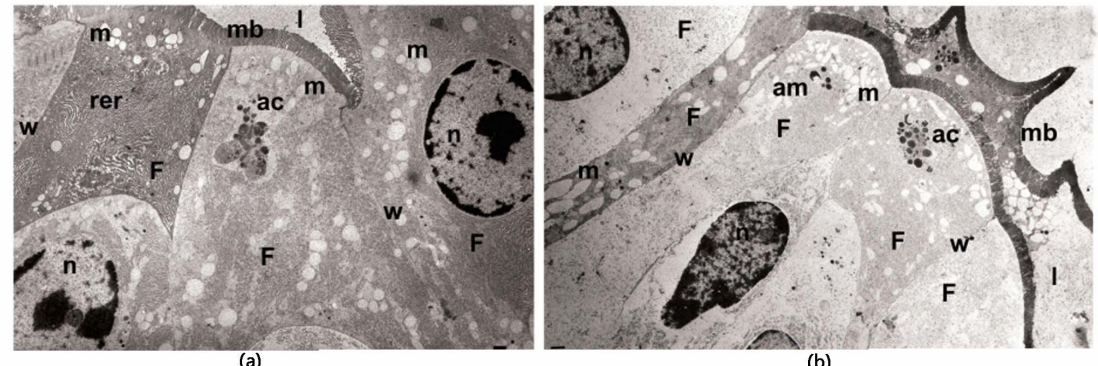

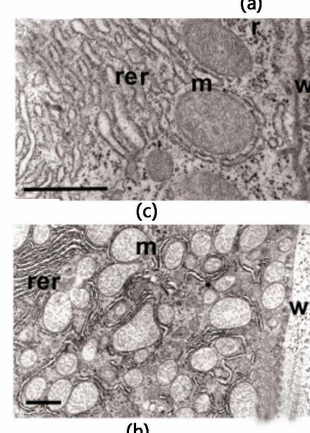

(h)

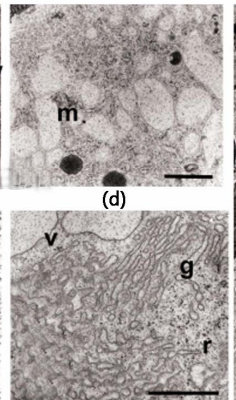

(i)

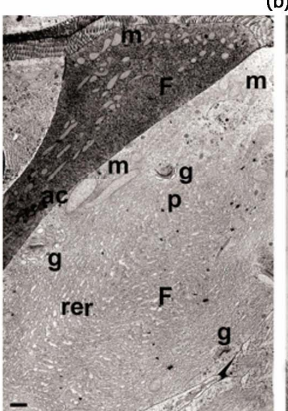

(f)

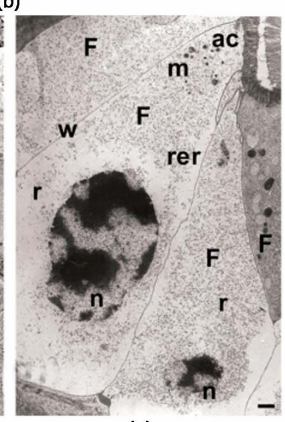

(g)

Figure 2. F-cell of Macrobrachium borellii and Palaemonetes argentinus from Alejandra (a and $\mathrm{f}$ respectively) and $\mathrm{N}^{\circ} 1$ lakes (b and g resepctively). Apical cell zone of $M$. borellii in $\mathrm{N}^{\circ} 1$ lake with lysis appearence of mitchondria, endoplasmic reticulum and glycoprotein granules (d). Basal zone of F-cell in M. borellii (c) sampled at Alejandra and P. argentinus cell (h and i) from both lakes with vesicles, golgi bodies and glycoprotein granules, endoplasmic reticulum forms cistern and vacuolizing dictyiosomes. Abbreviations: F-cell (F), rough endoplasmic reticulum (rer), golgi bodies (g), high electron density corpuscles (ac), lumen cell (1), microvillous border $(\mathrm{mb})$, mitochondria $(\mathrm{m})$, vesicles $(\mathrm{v})$, ribosomes $(\mathrm{r})$, peroxisomes (p), nucleus (n), wall cell (w). Bars: $0.1 \mu \mathrm{m}$ approximately.

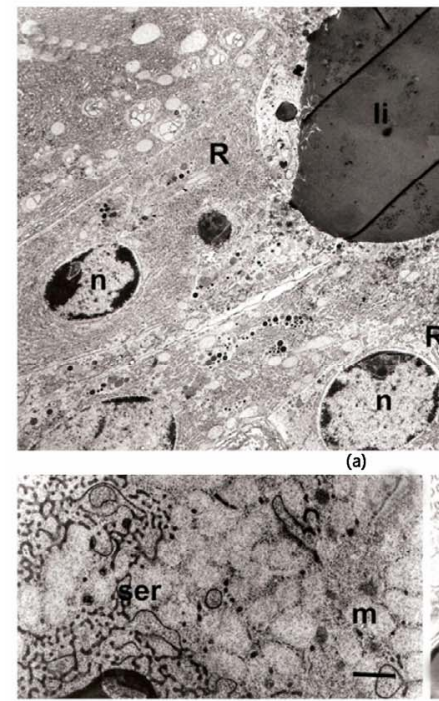

(d)

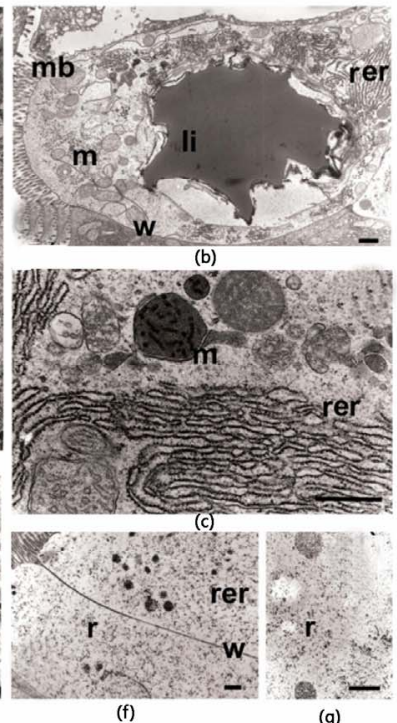

(g)

Figure 3. R-cell of Macrobrachium borellii and Palaemonetes argentinus affected in different levels from Alejandra and $\mathrm{N}^{\circ} 1$ lakes. Apical zone with microvillous border deteriorated, endoplasmic reticulum and shortened and mitochondria swelled, small vesicles, high electron density corpuscles and lipid vacuole with a multilayered membrane disrupted (a, b, e, f). Basal zone with endoplasmic reticulum vesiculated (rER and sER), glycoprotein granules and mitochondria swelled (in some R-cells were found a disrupted wall mitochondria) or with lysis appearance (c, d). Abbreviations: R-cell (R), rough endoplasmic reticulum (rer), smooth endoplasmic reticulum (ser), high electron density corpuscles (ac), lipid vacuole (li), microvillous border (mb), mitochondria (m), ribosomes (r), nucleus (n), wall cell (w). Bars: $0.1 \mu \mathrm{m}$ approximately. 


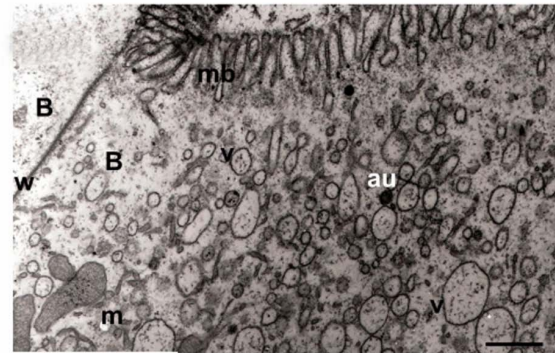

(a)

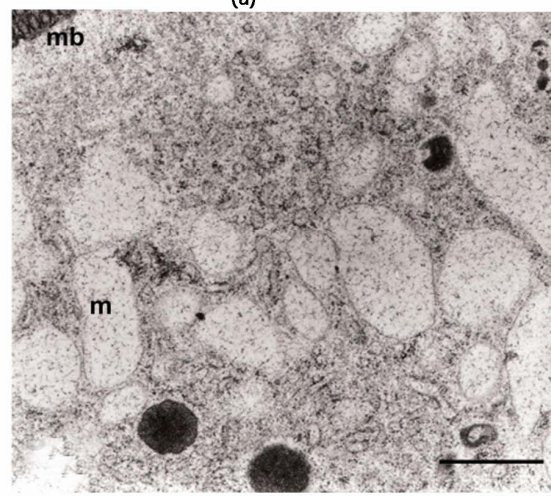

(c)

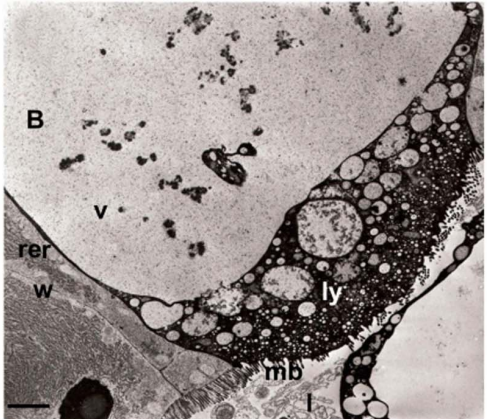

(b)

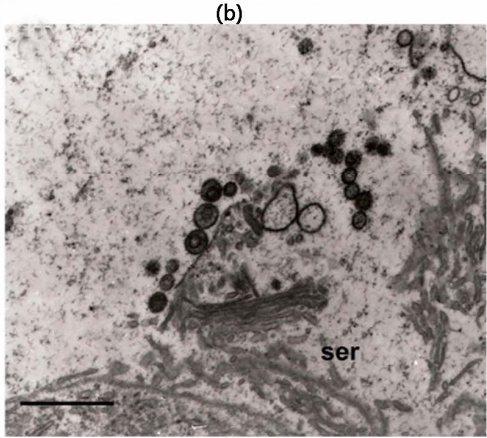

(d)

Figure 4. B-cell of Macrobrachium borellii and Palaemonetes argentinus from Alejandra and $\mathrm{N}^{\circ} 1$ lakes. Two moment of cell cycle without stress evidence $(a, b)$ but in some cell was observed organelles autolysis in cytoplasm (c, d). Abbreviations: B-cell (B), rough endoplasmic reticulum (rer), smooth endoplasmic reticulum (ser), autosomes (au), lumen cell (l), microvillous border (mb), mitochondria (m), vesicles (v), lisosomes (ly), wall cell (w). Bars: $0.1 \mu \mathrm{m}$ approximately.

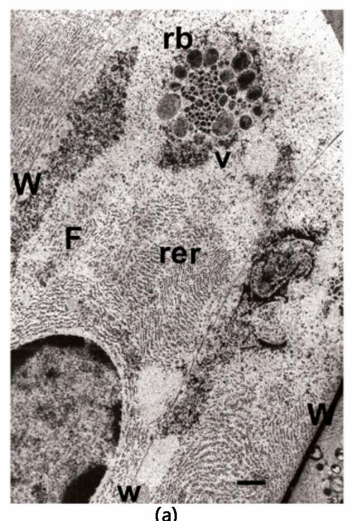

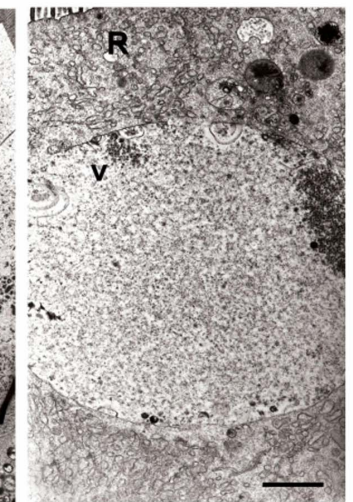

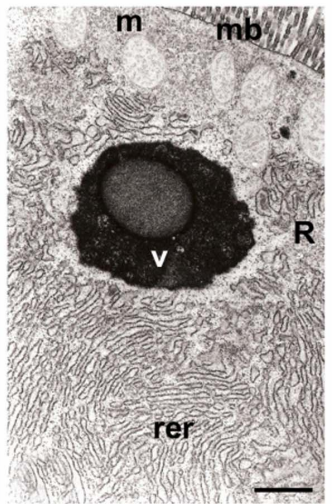

(d)

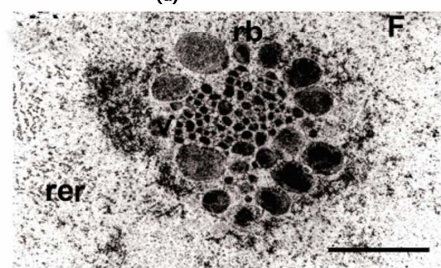

(b)

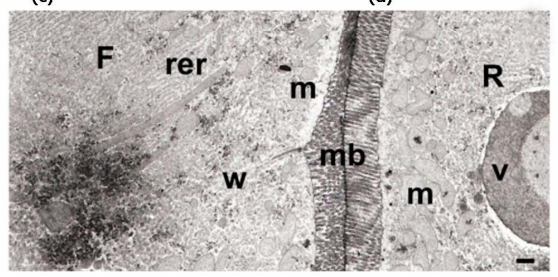

(e)

Figure 5. Others hepatopancreatic cell evidence of stress in Macrobrachium borellii and Palaemonetes argentinus from Alejandra and $\mathrm{N}^{\circ} 1$ lakes. Apical zone of F-cells with undefinible residual bodies and organelles autolysis. (a, b, e) In R-cells with differents vesicles without lipid content and swelled endoplasmc reticulum (c, d, e). Abbreviations: F-cell (F), R-cell (R), rough endoplasmic reticulum (rer), residual bodies $(\mathrm{rb})$, microvillous border $(\mathrm{mb})$, mitochondria $(\mathrm{m})$, vesicles (v), wall cell (w). Bars: $0.1 \mu \mathrm{m}$ approximately. 
perature (Table 2). The percentage of affected prawns was not different (ANOVA $p>0.005$ ) between the species M. borellii and P. argentinus. The " $\mathrm{N}^{\circ} 1$ " lake had the highest percentage of alterated cells in prawns with $75 \%$, $32 \%$ in Alejandra lake and only $9 \%$ in Don Felipe lake approximately. In this last one, the alterations coincided with the observations indicated as starvation effects (lipid dropplets with multilayered wall in R-cells). Moreover, the cell type frequency varied with the prawn origen (Don Felipe, $\mathrm{N}^{\circ} 1$ and Alejandra lakes), being the frequency of F-cells higher in prawns from $\mathrm{N}^{\circ} 1$ lake during samples of winter than other origin (Table 2).

In summer the number of affected cells disminished in all the lakes ( $45 \%$ in " $\mathrm{N}^{\circ} 1$ " lake, $26 \%$ in Alejandra lake and only $2 \%$ in Don Felipe lake approximately), and the cell type frequency was similar (Table 2).

\subsection{Laboratory Assays}

In both prawns, damaged hepatopancreatic cells by the pyretroid have had a relationship with the tested concentrations, being the cell frequency in each tested concentrations differents with the control at the end of the experience (ANOVA $F(0.05,2,22)=11.31 ; \mathrm{p}<0.0021)$. The F-cells were more abundant than all the others (Figure 6). The difference among $\mathrm{C} 2, \mathrm{C} 3$ and control, in the F-cell percentage, occurred during the second week whereas in the $\mathrm{C} 1$ it was in the third week (Figure 6). In the experience, the F-cell presence oscillated with changes significant among treated groups (Tukey's $\mathrm{p}>$ $0.05)$. The B-cell percentage in all cypermethrin concentrations were low, $12 \%(\mathrm{C} 1)$ and $19 \%(\mathrm{C} 3)$.

Prawn survivals in treated groups varied significantly during the 35 days of assays (ANOVA $F(0.05,2,22)=$ $350.64 ; \mathrm{p}<0.0001$, Tukey's $\mathrm{p}<0.05)$, and in the control group there had low mortality (Figure 6)

\section{DISCUSSION}

The hepatopancreas of both freshwater prawns ( $M$. borellii and $P$. argentinus), which consists of four cell types, undergoes ultrastructural changes depending on the quality of the environment. This fact was observed in the F-, R- and B-cells in different intensities. In these cells, microvilli border, endoplasmic reticulum and mitochondria were the most affected ultrastructure together with and the increase of residual bodies number. Moreover premature autolysis development was observed.

On the one hand, three measured parameters have differed, being the conductivity the most variable. Transparency reflected a great density of algae in the " $\mathrm{N}^{\circ} 1$ " lake before flooding period (November-April), which could be due to a nutrient rise. Also, this coincides with high DBO5 values. In the studied environments, different algae species can produce phytotoxins, exposing the prawns to this toxic stress. This situation could probably activate the antioxidant defences in the hepatopancreas leading to multiple oxidative processes and an effective detoxification [31]. The cytoskeleton could be destroyed by an increase in protein phosphorylation level, occurring cell necrosis [32]. The immune system responds with a melanization process which could act as a possible ROS scavenger [33]. Besides, the B-cell showed an intracell digestion what carried out, possibly, with posterior organelles degeneration in all cells, such as it was suggested in exposed crabs to microcystins [34]. Moreover the large vacuole of B-cells contains digestive enzimes, e.g. cathepsin L (MeCatL) [35]. It was recognized that in transicional cells F/B occurs P-glycoprotein (P-gp), suggesting a function in specialized cells for accumulation and elimination of toxic compounds [36].

On the other, many substances may be toxic taking into account their nature and amount, which are being released by industries and cities to fresh waters and/or the washing of farmlands during rains [37]. In these waste waters, the heavy metals could be important quantitatively, and these are toxic elements for decapods [38, 39]. Moreover, these xenobiotic elements were present in sites near to the cities, in other studies, several heavy

Table 3. Heavy metals measurements in sediment of several sites of Salado river close to the more affected sampling area (from a work [40]).

\begin{tabular}{cccccccc}
\hline Loc. & $\mathrm{Cu}$ & $\mathrm{Zn}$ & $\mathrm{Pb}$ & $\mathrm{Cd}$ & $\mathrm{Cr}$ & $\mathrm{Fe}$ & $\mathrm{Mn}$ \\
\hline 1 & 19.54 & 21.29 & 19.47 & n.d & 55.18 & 107.1 & 793.05 \\
2 & 0.78 & 0.05 & 1.9 & n.d. & 1.23 & 190.18 & 17.09 \\
17 & 1.03 & 0.21 & 1.03 & nd & 0.64 & nd & 1.77 \\
16 & 21.06 & 25.29 & 13.96 & nd & 9.71 & 560.92 & 182.26
\end{tabular}

values in $\mu \mathrm{g} / \mathrm{g}$; Localities: (1) Salado river in Motorway bridge (2 km up the river of " $\mathrm{N}^{\circ} 1$ " lake approximately), (2) Salado river in Santo Tomé-Santa Fe bridge (200 m down the river of " $\mathrm{N}^{\circ} 1$ " lake approximately), (17) Salado river in Recreo city (10 km up the river of " $\mathrm{N}^{\circ} 1$ " lake, approximately), (16) Las Prusianas river in Grutly (50 km up the river of " $\mathrm{N}^{\circ} 1$ " lake, approximately). 

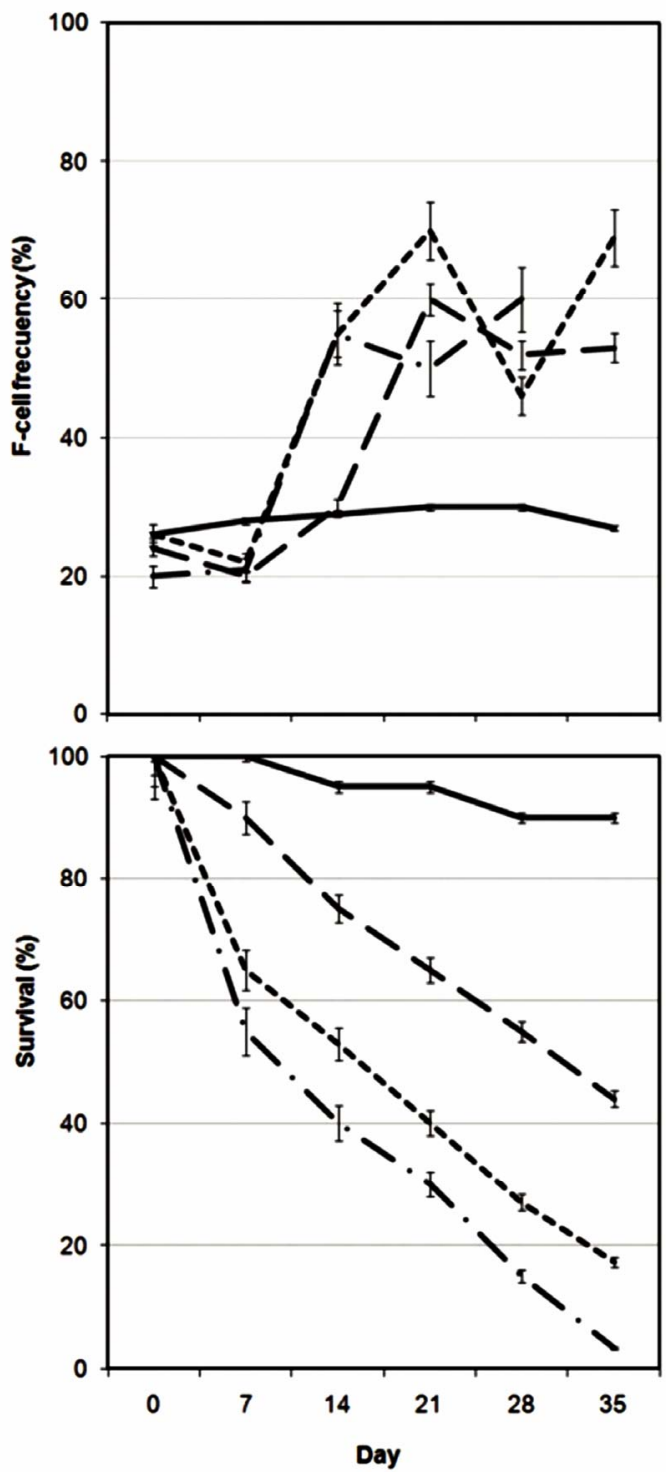

Figure 6. F-cell frequency and survival percentage of freshwater prawns (Macrobrachium borellii and $\mathrm{Pa}$ laemonetes argentinus) in the 35 days laboratory assays with several cypermethryn concentrations. Solid line: control groups; dash and point line: $0.01 \mu \mathrm{g}$ $\mathrm{CY} / 1$ groups; point line: $0.001 \mu \mathrm{g} \mathrm{CY} / 1$ groups; dashed line: $0.0001 \mu \mathrm{g} \mathrm{CY/1}$ groups).

metals were registered at different points of the Salado River sediments (Table 3), being a possible cause of potential stress effects. Another parameter that might provoke alterations in the prawns hepatopancreas is temperature but this do not suggest any alteration, due to the fact that lipid consumption for thermal stress occurs at $29^{\circ} \mathrm{C}$ in $M$. borellii [41], and the samplings were taken during spring (September-December) with lower temperatures.
Some of the observed changes in the hepatopancreatic cells were correlated with the starvation process and xenobiotics effects which were described for other decapods $[5,6,8,9,18,42,43]$. The affected prawns from $\mathrm{N}^{\circ} 1$ lake and the assay had similar evidence of stress in the hepatopancreas. The pyretroid is an biocid that it is used in non-urban and urban environments, and it could potentially get into the aquatic systems by different ways (e.g. perfution, rain drenage). This could induce to ROS production and to the formation of oxidative tissues in the hepatopancreas of prawns, while their cells have different biochemicals mechanisms to protect themselves from oxidative damage among which the glutathione plays an important role [44]. Different intrinsic factors such as specific capacity to stress tolerance, size, nutritional condition and extrinsic factors (e.g. temperature, conductivity, ph) are important to evaluate the populational effects in a natural environment. The high percentage of F-cells of exposed prawns to cypermethrin could indicate that some detoxification mechanisms is activated, including a more activity of the endoplasmic reticulum and ribosomes in this cell type than in others. The low number of B-cell could be interpreted as an increase of the exoxitation of the B-cells to hepatopancreas lumen. Moreover another efluents, e.g. oil product (PAH), provoked a size disminish in the hepatopancreas cells [43]. Furthermore, cell number varies significantly during the molt cycle (mainly, R-cell and F-cell) linked with a change in the enzimatic activity (ATPasas and $\mathrm{Na}$ /K ATPasas) [45], considering only the prawns in intermolt phase (c) by even.

The variation in the ultrastructure could have affected the absorption mechanisms and protein synthesis as observed by Papathanassiou and King [42]. However we could say that these prawns can tolerate some degree of environmental stress due to the fact that populations of these species were found in "Laguna $\mathrm{N}^{\circ} 1$ " lake with similar sizes [46] to those taken from environment with low human interference (Don Felipe lake) [25]. Thus we can infer that there must be some detoxification mechanisms such as those described by several authors $[18,38$, 47-51], where the F-cells could have a main rol. In these works it was also included the capture of transuranic elements, the deactivation of insecticides by rER or removal of metals by granule formulation and its excretion as detoxification pathways. These routes, together with that of the complete renewal of the epithelium occurring after several mitotic pulses [52] and/or some other mechanisms which involve a increase mitochondrial activity, could have allowed the presence of $M$. borellii and $P$. argentinus in this environment.

However, the detoxification is only feasible when the intensities of stressors do not exceed a particular thresh- 
old value, otherwise it produces cellular damage [13] and then the point-of-no return could be reached, such as it was observed in starved individuals of Penaeus monodon [9], and in this study according to the evidence in the cypermethrin assay.

\section{CONCLUSIONS}

The damage cell is irreversible to live of this prawn when the values achieved determined concentrations or stress level. The F-cell was increased with the intensities of the stressors such as mechanisms of detoxification. This involves a growth in numbers and size of rER, ribosomes, and mitochondria. Therefore, the reserves in the vacuole of R-cell are used to contribute to consume energy in the detoxification pathway. This justified the starvation conditions that is observed in some prawns.

The midgut glands of $M$. borellii and $P$. argentinus reacts to water quality variations, and the structural changes in cells and tissues represent the most sensitive level. It is showed the synergistic impact of an element, its metabolites and other exogenous and endogenous factors showing the hepatopancreas as a good tool in the determination of a stress areas of the natural environment.

\section{ACKNOWLEDGEMENTS}

The study was supported by a grant CONICET PIP 6275 (2006-2007).

\section{REFERENCES}

[1] Collins, P., Williner, V. and Giri, F. (2006) Trophic relationships in Crustacea Decapoda of a river with floodplain. In: Elewa, A.M.T., Ed., Predation in Organisms: $A$ Distinct Phenomenon, Springer Verlag, Heidelberg, 59-86.

[2] Gardi, C. (2001) Land use, agronomic management and water quality in a small Northern Italian watershed. $A g$ riculture Ecosystems \& Environment, 87(3), 1-12.

[3] Turner, R.E., Dortch, Q., Justic, D. and Swenson, E. (2002) Nitrogen loading into an urban estuary: Lake Pontchartrain (Louisiana, U.S.A.). Hydrobiologia, 487(1), 137-152.

[4] Friedler, E., Juanico, M. and Shelef, G. (2003) Simulation model of wastewater stabilization reservoirs. Ecological Engineering, 20(2), 121-145.

[5] Storch, V., Janssen, H.H. and Cases, E. (1982) The effects of starvation on the hepatopancreas of the coconut crab, Birgus latro (L.) (Crustacea, Decapoda). Zoologischer Anzeiger, 208(3-4), 115-123.

[6] Storch, V. and Anger, K. (1983) Influence of starvation and feeding on the hepatopancreas of larval Hyas araneus (Decapoda, Majidae). Helgoländer Meeresun, 36(1),
67-75.

[7] Storch, V. and Burkhardt, P. (1984) Influence of nutritional stress on the hepatopancreas of Talitrus saltator (Peracarida, Amphipoda). Helgoländer Meeresun, 38(1), 65-73.

[8] Anger, K., Storch, V., Anger, V. and Capuzzo, J.M. (1985) Effects of starvation on moult cycle and hepatopancreas of stage I lobster (Homarus americanus) larvae. Helgoländer Meeresun, 39(2), 107-116.

[9] Vogt, G., Storch, V., Quinitio, E. and Pascual, F. (1985) Midgut gland as monitor organ for the nutritional value of diets in Penaeus monodon (Decapoda). Aquaculture, 48(1), 1-12.

[10] Hryniewiecka-Szyfter, Z. and Storch, V. (1986) The influence of starvation and different diets on the hindgut of Isopoda (Mesidotea entomon, Oniscus asellus, Porcellio scaber). Protoplasma, 134(1), 53-59.

[11] Vogt, G., Quinitio, E. and Pascual, F. (1986) Leucaena leucocephala leaves in formulated feed for Penaeus monodon: A concrete example of the application of histology in nutrition research. Aquaculture, 59(3-4), 209234.

[12] Elendt, B.P. and Storch, V. (1990) Starvation-induced alterations of the ultrastructure of the midgut of Daphnia magna Straus, 1820 (Cladocera). Journal of Crustacean Biology, 10(1), 79-86.

[13] Triebskorn, R., Köhler, H.R., Zahn, T., Vogt, G., Ludwig, M., Rumpf, S., Kratzmann, M., Alberti, G. and Storch, V. (1991) Invertebrate cells as targets for hazardous substances. Zeitschfirt fuer Angewandte Zoologie, 78(3), 277-287.

[14] Vogt, G. (1992) Transformation of anterior midgut and hepatopancreas cells by Monodon Baculovirus (MBV) in Penaeus monodon postlarvae. Aquaculture, 107(2-3), 239-248.

[15] Vogt, G. (1996) Cytopathology of Bay of Piran Shrimp Virus (BPSV), a new Crustacean virus from Mediterranean Sea. Journal of Invertebrate Pathology, 68(3), 239-245.

[16] Vogt, G. (1997) Hepatopancreatic brush border lysis (HBL)-a new bacterial disease of the shrimp Palaemon elegans. Diseases of Aquatic Organisms, 29(2), 151-155.

[17] Bhavan, P. S. and Geraldine, P. (2000) Histopathology of the hepatopancreas and gills of the prawn Macrobrachium malcolmsonii exposure to endosulfan. Aquatic Toxicology, 50(4), 331-339.

[18] Vogt, G. (1987) Monitoring of environmental pollutants such as pesticides in prawn aquaculture by histological diagnosis. Aquaculture, 67(1), 157-164.

[19] Vogt, G. (1988) Anwendung der experimentellen Histologie zur Diagnostik in der Krebsaquakultur. In: Rosenthal, H., Saint-Paul, U. and Hilge, V., Eds., Perspektiven der Deutschen Aquakultur, Biologisches Anstalt Helgoland, Hamburg, 159-165.

[20] Shugart, L.R., Bickham, J., Jackim, G., McMahon, G., Ridley, W., Stein, J. and Sterinert, S. (1992) DNA alterations. In: Huggett, R.J., Kimerle, P.M., Mehrle, R.A. and Bergman, H.L., Eds., Biomarkers: Biochemical, Physiological and Histological Markers of Anthropogenic Stress, 
Lewis Publishers, Chelsea, 125-153.

[21] Bonetto, A.A. and Wais, I.R. (1995) Southern South American streams and rivers. In: Cushing, C.E., Cummins, K.W. and Minshall, G.W., Eds., Ecosystems of the World 22 River and Stream Ecosystems, Elsevier, Amsterdam, 257-293.

[22] Garcia de Emiliani, M.O. (1980) Fitoplancton de una laguna del valle aluvial del Paraná medio ("Los Matadores", Santa Fe, Argentina). I. Estructura y distribución en relación a factores ambientales. Ecología, 4(1), 127-140.

[23] Paggi, J.C. and Jose de Paggi, S. (1990) Zooplankton of the lotic and lentic environments of the Middle Paraná River. Acta Limnologica Brasiliensis, 3, 685-719.

[24] Devercelli, M. (2006) A morphological and functional approach to the phytoplankton of the Middle Paraná River during an anomalous hydrological period. Hydrobiologia, 563(1), 465-478.

[25] Collins, P. and Paggi, J.C. (1998) Feeding ecology of Macrobrachium borellii (Nobili) (Decapoda: Palaemonidae) in flood valley of the River Paraná, Argentina. $\mathrm{Hy}$ drobiologia, 362(1-3), 21-30.

[26] US EPA (1983) Chemical methods for the examination of water and wastes. EPA-600/4-79-020, United States Environmental Protection Agency, Environmental Monitoring and Support Laboratory, Cincinnati.

[27] APHA. (1998) Standard methods for the examination of water and wastewater. American Public Health Association, Philadelphia.

[28] Drach, P. and Tchernigovtzeff, C. (1967) Sur la methode de determination des stades d'intermue et son application general aux Crustaces. Vie et Milieu. Serie A. Biologie Marine, 18(A), 595-610.

[29] Collins, P. and Cappello, S. (2006) Cypermethrin toxicity to aquatic life: Bioassays for the freshwater prawn $\mathrm{Pa}-$ laemonetes argentinus. Archives of Environmental Contamination and Toxicology, 51(1), 79-85.

[30] Zar, J.H. (1996) Biostatistical analysis. 3rd Edition, Prentice Hall, New Jersey.

[31] Kankaanpä, H.T., Holliday, J., Schoreder, H., Goddard, T.J., Fister, R. and Carmichael, W.W. (2005) Cyanobacteria and prawn farming in northern New South Wales, Australia-a case study on cyanobacteria diversity and hepatotoxin bioaccumulation. Toxicology and Applied Pharmacology, 203(3), 243-256

[32] Dawson, R.M. (1998) The toxicology of microcystins. Toxicon, 36(7), 953-962.

[33] Nappi, A.J. and Vass, E. (1993) Melanogenesis and the generation of cytotoxic molecules during insect cellular immune-reactions. Pigment Cell Research, 6(3), 117-126.

[34] Pinho, G.L., Moura da Rosa, C., Yunes, J.S., Luquet, C.M., Bianchini, A. and Monserrat, J.M. (2003) Toxic effects of microsystins in the hepatopancreas of the estuarine crab Chasmagnathus granulatus (Decapoda, Grapsidae). Comparative Biochemistry and Physiology Part C, 135(4), 459-468.

[35] Hu, K.-J. and Leung, P.-C. (2004) Shrimp cathepsin L encoded by an introless gene has predominant expression in hepatopancreas, and occurs in the nucleus of oocyte. Comparative Biochemistry and Physiology Part B, 137(1), 21-33.

[36] Kölher, A., Lauritzen, B., Jansen, D., Bottcher, P., Tegu- liwa, L. and Krune, G. (1998) Detection of P-glycoprotein mediated MDR/MXR in Carcinus maenas hepatopancreas by immuno-gold-silver labeling. Marine Environmental Research, 46(1-5), 411-414.

[37] Montagna, M. and Collins, P.A. (2007) Survival and growth of Palaemonetes argentinus (Decapoda; Caridea) exposed to insecticides with chlorpyrifos and endosulfan as active element. Archives of Environmental Contamination and Toxicology, 53(3), 371-378.

[38] Vogt, G. and Quinitio, E.T. (1994) Accumulation and excretion of metal granules in the prawn, Penaeus monodon, exposed to water-borne copper, lead, iron and calcium. Aquatic Toxicology, 28(3-4), 223-241.

[39] Hook, S.E. and Lee, R.F. (2004) Genotoxicant induced DNA damage and repair in early and late developmental stages of the grass shrimp Paleomonetes pugio embryo as measured by the comet assay. Aquatic Toxicology, 66(1), $1-14$.

[40] INALI, (1997) Conservación manejo de ecosistemas acuáticos continentales. Contaminación y acuicultura (PID-BID 0230), 1994-1997, Conicet, Santo Tomé.

[41] Pollero, R.J., Baró, G., delR, M. and Irazú, C.E. (1991) Lipid classes consumption related to fasting and thermal stress in the shrimp Macrobrachium borellii. Comparative Biochemistry and Physiology, 99B, 243-249.

[42] Papathanassiou, E. and King, P.E. (1984) Effects of starvation on the fine structure of the hepatopancreas in the common prawn Palaemon serratus (Pennant). Comparative Biochemistry and Physiology, 77A, 243-249.

[43] Yamuna, A., Kabila, V. and Geraldine, P. (1996) Biochemical and histological alterations in the prawn Macrobrachium lamerrei following exposure to automobile discharge. GeoJournal, 40(1-5), 233-237.

[44] Cairrao, E., Couderchet, M., Soares, A.M. and Guilhermino, L. (2004) Glutathione-S-transferase activity of Fucus spp. as a biomarker of environmental contamination. Aquatic Toxicology, 70(4), 277-286.

[45] Zilli, L., Schiavone, R., Scordella, G., Zonno, V., Verri, T., Storelli, C. and Vilella, S. (2003) Changes in cell type composition and enzymatic activities in the hepatopancreas of Marsupenaeus japonicus during the moulting cycle. Journal of Comparative Physiology B, 173(4), 355-363.

[46] Collins, P. (1997) Ritmo diario de alimentación en el camarón Macrobrachium borellii (Decapoda, Palaemonidae). Iheringia Série Zoologia, 82(1), 19-24.

[47] Guary, J.C. and Négrel, R. (1981) Calcium phosphate granules: A trap for transuranic and iron in crab hepatopancreas. Comparative Biochemistry and Physiology, 68A, 423-427.

[48] Lyon, R. and Sinkiss, K. (1984) The ultrastructure and metal containing inclusions of mature cell types in the hepatopancreas of a crayfish. Tissue Cell, 16(5), 805-817.

[49] Nott, J.A. (1991) Cytology of pollutant metals in marine invertebrate: A review of microanalytical applications. Scanning Microscopy, 5(1), 133-142.

[50] Roldan, B.M. and Shivers, R.R. (1987) The uptake and storage of iron and lead in cells of the crayfish (Orconectes propinguus) hepatopancreas and antennal gland. Comparative Biochemistry and Physiology, 86C, 201214.

[51] Vogt, G. (1990) Pathology of midgut gland-cells of Pe- 
naeus monodon postlarvae after Leucaena leucoce-phala feeding. Disease of Aquatic Organisms, 9(1), 45-61.

[52] Hopkin, S.P. and Nott, J.A. (1980) Studies on the digestive cycle of the shore crab Carcinus maenas (L.) with special reference to the B-cells in the hepatopancreas. Journal of the Marine Biological Association of the United Kingdom, 60(1), 891-907. 